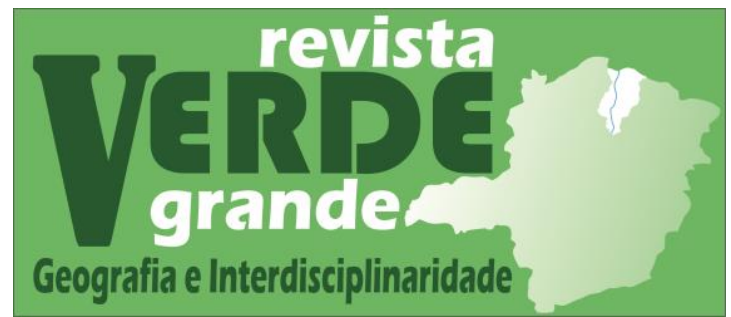

\title{
RESENHA
}

\section{ALMANAQUE DE AGROECOLOGIA: APRENDENDO COM DIVERSÃO - DIVERSIDADE, HISTÓRIA E CULTURA ALIMENTAR}

Eliana Izabel da Silva Cepolini ${ }^{1}$ https://orcid.org/0000-0002-1836-0544

\footnotetext{
${ }^{1}$ Graduanda em Ciências Biológicas - Universidade de Taubaté. E-mail: eliana.izabel.silva@gmail.com
}

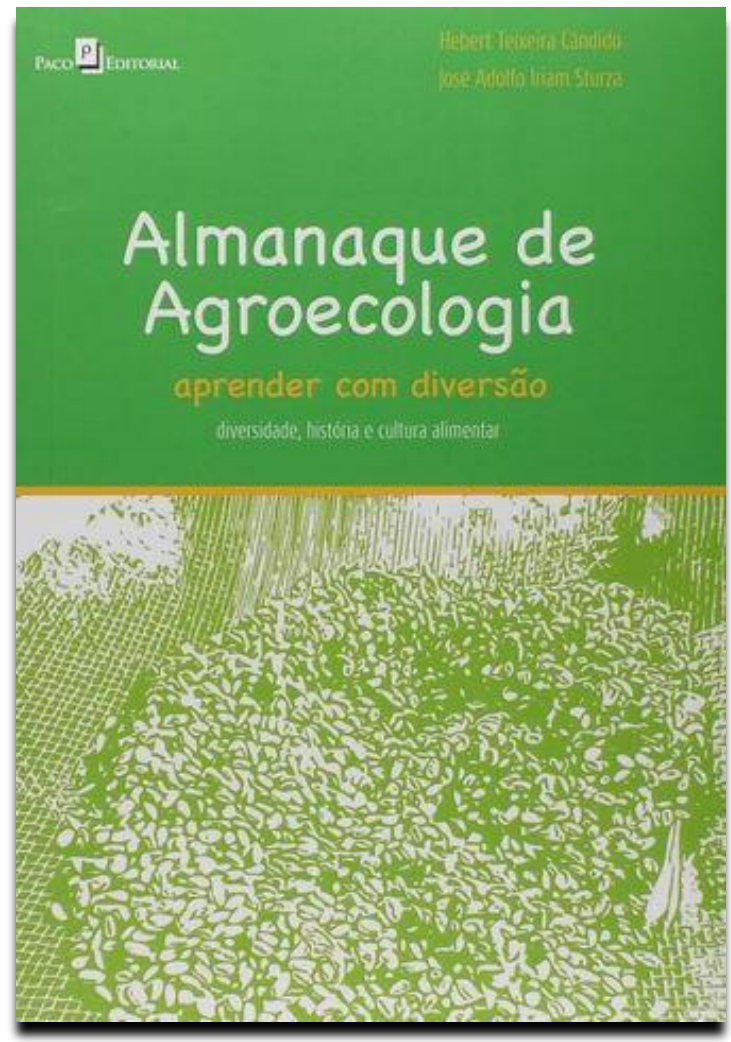

A obra "Almanaque de Agroecologia: aprendendo com diversão - diversidade, história e cultura alimentar" dos pesquisadores Hebert Teixeira Cândido e José Adolfo Iriam Sturza representa um exímio esforço didático para além dos muros acadêmicos. Tal constatação pode ser lida e relida na capa, desenhos, rimas, caça palavras, cruzadinhas, atividades, glossário, referências e, sobremaneira, no prefácio.

O Almanaque de Agroecologia é divido em quatro seções articuladas, quais sejam: prefácio, almanaque, glossário e referências. No prefácio escrito por autor Hebert Teixeira 
Cândido, nota-se as práticas agroecológicas na sua trajetória pessoal e profissional. Nesse devir, faz um convite para as crianças e famílias despertarem para o respeito à mãe terra, ou seja, o redescobrimento de práticas históricas que remetem aos alimentos, receitas culinárias e práticas agronômicas. Por isso, afirma: "no presente trabalho, buscou apresentar a Agroecologia em suas mais variadas ciências, para essa que já se caracteriza por ser uma ciência interdisciplinar [...]" (CÂNDIDO; 2019, p. 09).

$\mathrm{Na}$ sequência do Almanaque destacam-se as atividades que remetem aos temas centrais da Agroecologia; alimentos regionais (Norte, Sul, Centro Oeste e Nordeste do Brasil), horta mandala, contribuição africana, indígena e portuguesa na nossa alimentação, adubos verdes, macros e micronutrientes utilizados pelas plantas, entre outras frutas e sua distribuição e importância regional em consonância com a perspectiva da biodiversidade. Encerrando essa segunda parte, os autores citam o Engenheiro Agrônomo Sérgio Ricardo Matos Almeida (2012) e sua exímia Pedagogia em Rimas, ou mesmo, Agroecologia em Rimas:

A Agroecologia é Ciência multidisciplinar Propõe produção limpa E sustentabilidade já. Traz para a agricultura Profundidade e beleza, Pensamento Ecológico, Diálogo com a Natureza.

Promove integração, De maneira essencial, Da verdade científica Com o saber tradicional. Trata causas e não sintomas

Nas questões estudadas,

E com visão sistêmica São, então, solucionadas.

Praga não é castigo Mas aliada, com certeza. Quando se erra no manejo, É o sinal da Natureza. Agricultura Orgânica É prática de valor, Pois protege a saúde Do sábio agricultor. Não usa agroquímicos, produz sem contaminar,

Conserva o ambiente

A terra, a água e o ar.

$\mathrm{O}$ agroecossistema É diversificado, A proteção do solo É cuidado proclamado.

É conjunto de técnicas, Normas e procedimentos, 
Após essa breve e importante indicação, os autores entram na parte mais extensa do Almanaque, ou seja, o Glossário com suas 149 palavras - conceitos, temas e contextos envolvendo a agroecologia e seus desdobramentos, sobretudo, no Brasil, devidamente fundamentadas com as 132 referências bibliográficas indicadas; revelando a aderência entre pesquisa, ensino e extensão presente na obra.

Nesse sentido, cabe reafirmar o compromisso dos autores em difundir os saberes agroecológicos a partir de um olhar interdisciplinar e simultaneamente ofertar um material para todas as pessoas independentemente da idade. Trata-se, portanto, de um guia repleto de informações devidamente organizadas para propiciar aproximações, bem como novas pesquisas e ações frente à gigantesca sociobiodiversidade brasileira.

Por fim, cabe salientar a indicação para a Educação Básica e todas e todos que se interessam por alimentação agroecológica, alimentos regionais, biodiversidade, entre outros temas que convergem no cuidado comum com o Planeta Terra.

\section{Referências}

Almeida, Sérgio Ricardo Matos. Agroecologia em rimas. Cruz das Almas: UFRB, 2012.

CÂNDIDO; Hebert Teixeira; STURZA, José Adolfo Iriam. Almanaque de Agroecologia: aprendendo com diversão - diversidade, história e cultura alimentar. Jundiaí-SP: Paco, 2019. $60 \mathrm{p}$.

CÂNDIDO; Hebert Teixeira. Prefácio. In: CÂNDIDO; Hebert Teixeira; STURZA, José Adolfo Iriam. Almanaque de Agroecologia: aprendendo com diversão - diversidade, história e cultura alimentar. Jundiaí-SP: Paco, 2019. 60p. 